John J. Binder

\title{
The Transportation Revolution and Antebellum Sectional Disagreement
}

The transportation revolution had several important effects on the antebellum political equilibrium. First, it caused mestern and southern political viems to differ by bringing more easterners and European immigrants into the West. Second, it reduced the costs of rerouting mestern exports to the non-South, which decreased the expected costs to the West of conflict with the South. Third, it greatly increased mestern population, which brought more free states into the Union and changed the balance in the Senate. Fourth, it increased northern numerical superiority over the South, giving the North a major advantage if an armed conflict did occur. These changes led the West to ally with the East and caused the South to secede.

When we consider the causes of the sectional conflict, we must ask ourselves not only why civil war came when it did, but why it did not come sooner. How did a divided nation manage to hold itself together for as long as it did? (Eric Foner, Politics and Ideology in the Age of the Civil War)

The argument that an escalating sectional conflict between North and South before April 1861 produced war between them after that date does not really explain why a conflict of long duration produced war then and not at some other time. The problem is how a basic conflict between sectional interest and values that had long been carried on in peaceful channels such as politics abruptly became a shooting war after smoldering for decades, and why it did so at one time instead of at another. What produced the sectional hostility, in other words, was not necessarily what caused armed conflict in 1861. (Michael F. Holt, The Political Crisis of the 1850s)

Social Science History 35:1 (Spring 2011)

DOI 10.1215/01455532-2010-016

C 2011 by Social Science History Association 
During the antebellum period, there were two major revolutions. In the political revolution of the $1850 \mathrm{~s}$, the West, which earlier had aligned with the South, joined with the East. Traditional political parties fragmented, and new, sectional parties arose. Secession and the Civil War soon followed. The transportation revolution reduced shipping costs between the East and the West and changed the direction of East-West trade from the U-shaped southern routes to direct northern routes. The relation between these two changes has not, however, been fully appreciated.

The transportation revolution had two major effects on the political equilibrium. The reduction in transportation costs on the northern routes between the West and the East (and foreign markets), relative to those on southern routes, reduced an obstacle (cost) that previously had deterred the North from political hostility toward the South. If before the transportation revolution the West had allied with the East, the probability of southern secession, civil war, and the closing of the Mississippi River would have increased. Since the costs of rerouting trade were large, the expected costs of western political action were also large. By the 1850s the increased costs of shipping directly east-west were small, and the expected costs of political action were much smaller. The per capita decrease in transportation costs was greatest for the West. Because the West held the balance of power between the sections, this shift changed the political equilibrium (if the West was willing to ally with the East).

Besides lowering the relative cost on the northern routes, the transportation revolution brought easterners and European immigrants to the West and increased the population of the North relative to the South. The influx of nonsoutherners changed political attitudes in the West, because earlier most westerners were transplanted southerners. This also altered the political balance in Congress, because it increased the number of senators from the free states. Furthermore, it increased northern numerical and economic superiority. In response to these changes the South seceded to escape what it saw as further abuse by the North.

In summary, the transportation revolution caused the sections to disagree, and it lowered the expected costs to the North of disagreement. While the change in the composition of northern population has been discussed previously, the importance of the decrease in the costs of switching western exports to the northern routes and the other effects of the transportation revolution appears to have gone largely unnoticed. ${ }^{1}$ 


\section{Antebellum Sectional Politics}

\section{Political Compromise and Disagreement}

The period before 1860 was one of intense debate about sectional issues. ${ }^{2}$ Certainly by 1820 most of the suggested causes of the Civil War were already major issues. Despite these differences, at least two major compromises occurred before 1861: the Missouri Compromise in 1820 and the Compromise of 1850. After 1850 compromise no longer seemed possible. The Kansas-Nebraska Act of 1854 was more a repudiation of compromise than a continuation of it. By extending popular sovereignty to Kansas and Nebraska, the act rescinded the major feature of the Missouri Compromise and angered many northerners. Even John J. Crittenden's proposal to restore and extend to the Pacific Ocean the prohibition of slavery above the Missouri Compromise line of $36^{\circ} 30^{\prime}$ north latitude fell on deaf ears.

Meanwhile, there was a major change in sectional alignments during the 1850 s. Previously the agrarian interests in the South and the West generally had allied against the eastern business interests (Riker 1982). Just before the war, the West joined the East in a new coalition against the South. The Republican Party, founded in 1854, captured a plurality of the seats in the House of Representatives in the 1854 elections and a third of the votes in the 1856 presidential election (Nevins 1947; Gienapp 1987).

There are several hypotheses in the literature about why sectional relations deteriorated during the 1850 s. One notes that by 1850 free states would soon outnumber slave states. Anticipating this, the South looked to secession to protect itself (Stampp 1990: 124). Alternatively, Eric Foner (1980: chap. 3) cites the rise of sectional ideologies, which destroyed the national coalitions forged by the Whigs and Democrats, as the major change. To Foner, the major political parties in 1850 were the glue that held the sections together. Michael F. Holt (1978) argues that during the 1850 s voters became distrustful of politicians and the existing parties. This spawned new, ideological parties. Holt agrees with Foner that the decline of the existing parties severed the link between the sections.

These hypotheses are open to question. For instance, from March 1803 to April 1812 there were nine free states and eight slave states. Similarly, after 1850 free states outnumbered slave states, yet the war did not occur until 1861. Therefore the imbalance between the free states and slave states, which was also due to the transportation revolution, does not by itself explain the timing 
of the conflict. Regarding the Foner and Holt hypotheses, is the rise of sectional ideology the problem, or did sectional disagreements intensify because the cost of conflict decreased? If the latter is true, existing parties would also have collapsed and been replaced by sectional ones. Similarly, did political satisfaction decrease, or did disagreement over sectional issues increase, leaving voters disenchanted with the existing parties? These hypotheses do not explain why sectional ideologies arose or why the West became agitated against the South in the 1850 s.

\section{The Expected Costs and Benefits} of Sectional Conflict

Before pressing an issue, rational agents would analyze the expected costs and benefits. For simplicity, assume that the sections disagreed about the expansion of slavery and that it was known that this might lead to secession and also civil war. ${ }^{3}$ There was clearly some expected (ideological) benefit to political action, because people spent resources on it. There were also important expected costs in terms of human suffering and loss of wealth. The loss of wealth includes the opportunity costs of producing war materials, the lost trade between the North and the South, and the effects of closing the Mississippi River to East-West trade during a war.

Denote an individual's wealth if there is no sectional disagreement as $W$. The benefits of sectional disagreement and the costs of civil war (measured in dollars) equal $B$ and $C$, respectively. Assume, with no loss of generality, that with sectional disagreement civil war will follow with probability 1 and that the probability of a person's section winning the war is $p_{w}$. The benefits $B$ are received only if the person's section wins the war. ${ }^{4}$ An individual's utility equals $U(W)$ if there is no sectional disagreement, and expected utility if there is sectional disagreement equals:

$$
E[U(W)]=p_{w} U(W+B-C)+\left(1-p_{w}\right) U(W-C)
$$

For an individual whose utility increases with wealth to favor sectional disagreement, $B$ must be greater than $C$. On the other hand, if $C$ equals 0 , a person with a positive $B$ favors sectional disagreement. Of direct interest here, a decrease in $C$ causes some individuals to switch from opposing disagreement to preferring it, as does an increase in $p_{w}$. Although the costs per 
capita of human suffering, producing war materials, and lost trade may not have changed greatly during the antebellum period, the cost of switching to northern transportation routes did decrease..$^{5} \mathrm{~A}$ decrease in the added costs of using the northern routes (or an increase in $p_{m}$ ) would have led to greater political disagreement between the sections, increasing the probability that existing political parties would fragment, the South would secede, and civil war would follow. While a small change in $C$ or $p_{w}$ might have caused some people to change their political stance, it is more likely that these changes influenced behavior if they were large. Shipping costs during the antebellum period are examined in the next section, including the costs of using northern as opposed to southern routes.

\section{The Transportation Revolution}

\section{Canals, Railroads, and East-West Trade}

Before the Erie Canal opened in 1825, virtually all trade between the East and the West used the Mississippi River and connecting waterways. ${ }^{6}$ The Erie prompted further canal building, largely in the North, which was mostly completed by 1840 . American railroads were in their infancy in $1830 .^{7}$ Even in 1850 Illinois and Wisconsin had very little track, and there was none west of the Mississippi River. ${ }^{8}$ Nor was it possible to go by rail from Ohio to the Atlantic in 1850, since no railroad ran across Pennsylvania. ${ }^{9}$ By 1855 railroads connected Illinois to the East Coast, fed by lines from Missouri, Iowa, and Wisconsin to Chicago.

The transportation revolution greatly altered the direction of East-West trade. In 1816 almost all western produce consumed by the non-South went through New Orleans, while in 1861 the opposite was true (Fishlow 1965: 284, table 39; North 1966: chap. 11). Although the direction of trade between the West and the non-South changed, this does not necessarily mean that the differential cost of using the northern routes was large (and politically important) before the advent of canals and railroads. For example, a slight decrease in the cost of using the northern routes may have altered the direction of trade, but a small cost of switching to the direct routes would have been of minor political importance.

To estimate the costs of rerouting western exports, transportation costs from Pittsburgh, Cincinnati, St. Louis, Detroit, and Chicago to New York 
City, the major eastern destination of this trade, are examined. The costs are estimated for 1816 (before the transportation revolution) and for 1853 (when the political equilibrium was changing). Table 1 lists the lowest-cost routes used in the analysis and the method of transportation on each route segment. ${ }^{10}$ The cheapest routes of each type to New York City are the same as those from New York City, with the exception of the southern route from Detroit in 1853. ${ }^{11}$ Because in 1853 the northern routes with the lowest out-of-pocket costs used canals rather than railroads, only canal routes are examined. Railroads were of course used to ship some commodities in 1853, making the total costs of shipping some items on the northern routes lower than the figures based on using canals. ${ }^{12}$

Before the transportation revolution, all the northern routes involved land travel. On the other hand, the major western cities at the timePittsburgh, Cincinnati, and St. Louis - could be reached entirely by water via New Orleans, and Chicago and Detroit required only short trips overland. The lowest-cost southern routes were, with one exception, the same in 1853 as in 1816, making only limited use of the canals at the later date. However, the lowest-cost northern routes in 1853 used artificial means of transportation in each case.

\section{Freight Rates for Various Means of Transportation}

During the antebellum period, western exports were primarily farm products, while western imports were mostly factory goods. Rates by wagon, river, lake, and canal were quoted in a similar fashion: unless a specific rate was set for an item, the general merchandise rate, charged per 100 pounds (hundredweight), applied. This was true for western produce and eastern goods. At times a distinction in the general rate was made between light and heavy merchandise. On a few agricultural commodities, moreover, rates were set per container. For example, rates were quoted per barrel of flour, bushel of grain, or bale of cotton. Ocean freight rates were quoted differently. For agricultural products shipped from New Orleans, the freighting unit was generally the ton, and by antebellum standards various quantities equaled a ton. For example, 8 barrels of flour (as opposed to 6 barrels of beef), 40 cubic feet of timber, or the same volume of cotton equaled 1 ton. ${ }^{13}$ Freight shipped from New York City to New Orleans was based on the ton, the cubic foot, the box, the barrel, the keg, or the unit, depending on the item. 
To estimate the increase in transportation costs if East-West trade switched from the southern to the northern routes, ideally data would be collected for a single commodity, such as flour, on both routes. Unfortunately, data are not as readily available during the period before 1860 as they are for later years, and items tended to move largely in one direction. William J. McAlpine (1854: 151, table W), however, collected data on freight rates (including tolls) per ton mile for shipping over the major routes in 1853 for various means of transportation. Further data for that year are reported by Thomas S. Berry (1943). George Rogers Taylor (1976: 442, table 2) presents figures for 1816 and surrounding years. Therefore the major transportation cost comparisons are based on freight rates and tolls in 1816 and 1853.

The McAlpine or Taylor figures are used for the year in question unless rates per ton mile varied by direction or by distance on a given route segment. ${ }^{14}$ When other data are used, actual rates are preferred to estimates based on, for example, passenger rates. If an actual rate for the year is not available, the actual rate from the nearest year is used. The McAlpine data are used in every case in 1853, except for the ocean rates between New York City and New Orleans, the Erie Canal rates, and the eastbound rates on the Great Lakes. For 1816 the Taylor data are used for river transportation and for land routes connecting New York City to Philadelphia and Chicago to LaSalle, Illinois. The remaining estimates for 1816 are from other sources. ${ }^{15}$

Overall, the data for 1853 are quite good. Most of the figures were collected by experts on transportation, and in the other cases the estimates appear to be very accurate. The data for 1816 also appear to be quite reasonable. Table 2, which summarizes the data, contains estimates of the cost to ship a ton of freight one mile on each route segment listed in table 1. The figures in parentheses are the rates for shipping in the opposite direction. For example, the 1816 rate per ton mile from Albany to Buffalo was about 31 cents, while it cost 34 cents per ton mile to ship from Buffalo to Albany. Some brief comments about the freight rates are in order. ${ }^{16}$ In 1816 the freight rate by wagon on turnpikes was around 33 cents per ton mile for most routes, noticeably above freight rates for other means of transportation. River rates, based on the estimates for the Mississippi, are a function of the technology available in 1816. While flatboats could be floated downriver, shipping upriver by keelboat or steamboat was more expensive.

The transportation revolution dramatically decreased freight rates from 1816 to 1853 . Ocean rates dropped by $50-90$ percent. Westbound rates on 


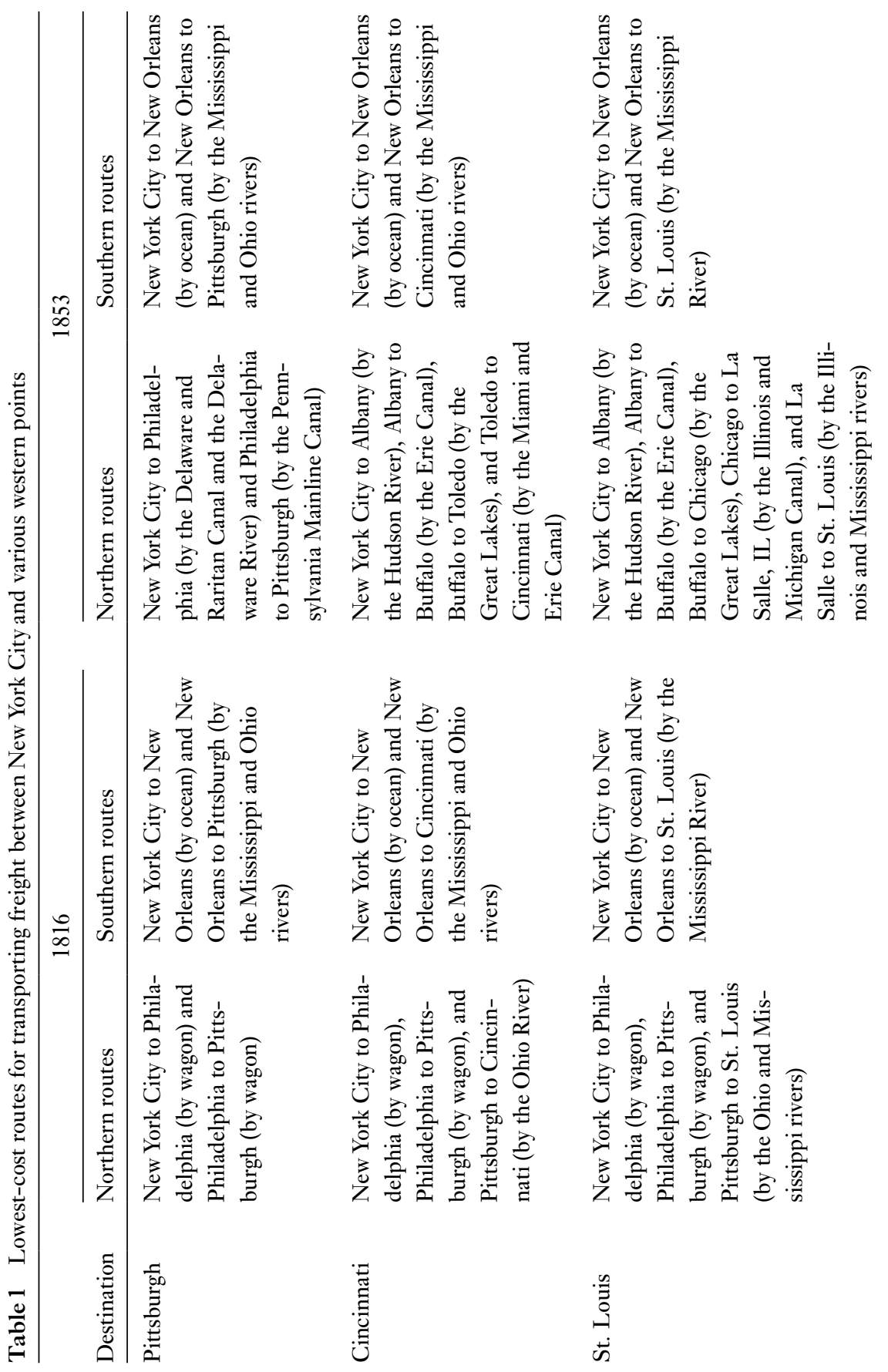




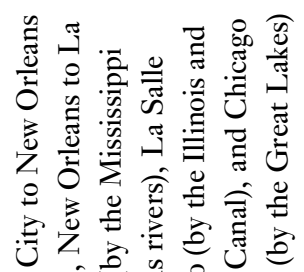

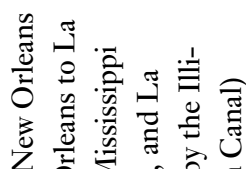

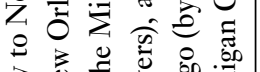

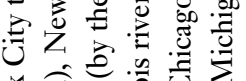

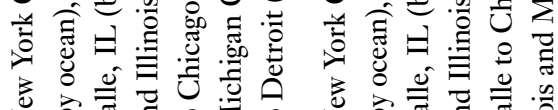

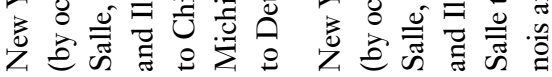

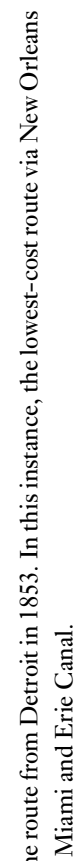

它竞

吾高

产产

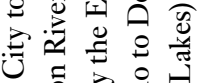

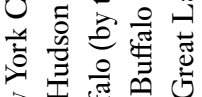

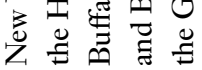

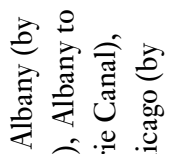

席绖

氙完至

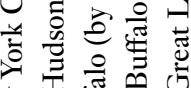

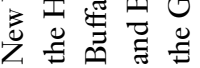

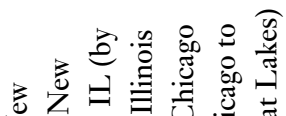

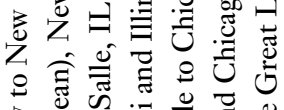

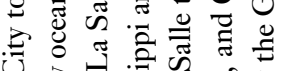

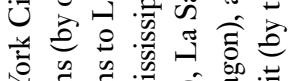

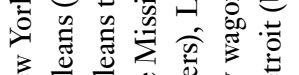

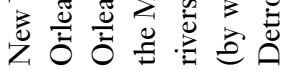

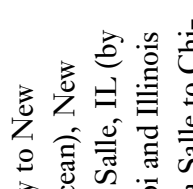

응

它包要焉

की

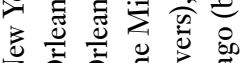

을

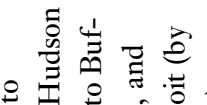

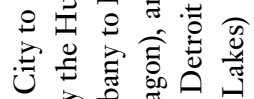

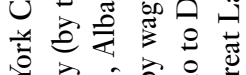

宅它焉

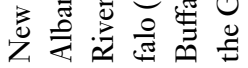

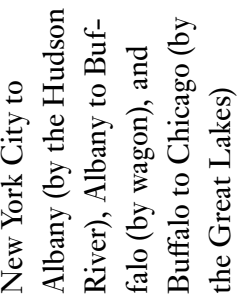

อั๊

:

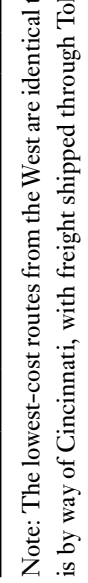


Table 2 Estimated freight rates, including tolls, in dollars per ton mile for shipping by various methods of transportation (and for shipping in the opposite direction)

\begin{tabular}{|c|c|c|}
\hline Method of transportation and route & 1816 & 1853 \\
\hline \multicolumn{3}{|l|}{ Road } \\
\hline New York City to Philadelphia & $0.333(0.333)$ & NA \\
\hline Philadelphia to Pittsburgh & $0.383(0.141)$ & NA \\
\hline Albany to Buffalo & $0.308(0.336)$ & NA \\
\hline La Salle, IL, to Chicago & $0.333(0.333)$ & NA \\
\hline \multicolumn{3}{|l|}{ Ocean } \\
\hline New York to New Orleans & $0.027(0.006)$ & $0.004(0.003)$ \\
\hline \multicolumn{3}{|l|}{ Lake } \\
\hline Buffalo to Toledo & NA & $0.010(0.006)$ \\
\hline Buffalo to Detroit & $0.063(0.007)$ & $0.010(0.005)$ \\
\hline Buffalo to Chicago & $0.039(0.009)$ & $0.005(0.003)$ \\
\hline Toledo to Detroit & NA & $0.050(0.024)$ \\
\hline Detroit to Chicago & $0.052(0.011)$ & $0.005(0.004)$ \\
\hline \multicolumn{3}{|l|}{ River $^{a}$} \\
\hline Hudson & $0.058(0.013)$ & $0.007(0.007)$ \\
\hline Ohio & $0.058(0.013)$ & $0.008(0.008)$ \\
\hline Illinois & $0.058(0.013)$ & $0.012(0.012)$ \\
\hline Delaware & NA & $0.012(0.012)$ \\
\hline \multicolumn{3}{|l|}{ Mississippi } \\
\hline Upper river & $0.058(0.013)$ & $0.009(0.009)$ \\
\hline Lower river & $0.058(0.013)$ & $0.006(0.006)$ \\
\hline \multicolumn{3}{|l|}{ Canal } \\
\hline Pennsylvania Mainline & NA & $0.024(0.024)$ \\
\hline Delaware and Raritan & NA & $0.011(0.011)$ \\
\hline Miami and Erie & NA & $0.010(0.010)$ \\
\hline Illinois and Michigan & NA & $0.014(0.014)$ \\
\hline Erie $^{\mathrm{b}}$ & NA & $0.014(0.015)$ \\
\hline
\end{tabular}

${ }^{a}$ The rates on the rivers are for upstream shipments (downstream rates in parentheses).

${ }^{b}$ The rate on the Erie Canal is from Albany to Buffalo (rate on the reverse route in parentheses).

the Great Lakes fell by $80-90$ percent, while eastbound rates fell by a half to two-thirds. Although downriver rates did not fall as much as other rates, upriver rates did, equalizing the two by 1853 at the latest. ${ }^{17}$ The greatest decrease in shipping costs occurred between points connected by land in 1816, such as Albany and Buffalo. The freight rates between such cities fell by over 90 percent, making the northern routes competitive with the southern ones. 


\section{Transportation Costs on the Northern} and Southern Routes

The estimated costs of shipping a ton of freight to New York City in 1816 and 1853 are reported in table 3 . The transportation charge over a given route segment equals the rate per ton mile multiplied by the distance. ${ }^{18}$ The costs of shipping through New Orleans in 1816 (reported in the 1816 southern route panel of the table) varied greatly by location. In 1816 a ton of freight could be sent from St. Louis to New York for $\$ 25.98$, for slightly more from Cincinnati and Pittsburgh, but for $\$ 63.36$ from Chicago and $\$ 96.42$ from Detroit. The average cost of sending a ton of freight by the southern routes in 1816 was $\$ 50.49$. The costs of shipping to New York on the northern routes in 1816 were noticeably higher, ranging from $\$ 72.26$ per ton from Pittsburgh to $\$ 128.56$ per ton from St. Louis. The average cost of sending freight directly east in 1816 from these five points is estimated as $\$ 102.82$ per ton.

The estimates are consistent with the known facts about the West and commerce during this period. The upper West was sparsely populated in 1816, because it was very expensive to send goods to market from there. ${ }^{19}$ Instead, most of the population lived along the Mississippi and Ohio rivers. Almost all western exports went by the southern route, because it was cheaper. ${ }^{20}$ Even Pittsburgh shipped to the East almost entirely via New Orleans in 1816, with wagons from Philadelphia often returning empty (Berry 1943: 74). The increase in the costs of shipping from the West in 1816 if the southern routes had closed is estimated by subtracting the cost on the southern route from the cost on the northern route. Because the increase in cost (if any) is of interest, the figure is set to 0 if the difference is negative. The differential costs are in the third column of the 1816 panel of table 3 . The differential cost was $\$ 35.85$ (per ton) from Pittsburgh, $\$ 46.51$ from Chicago, $\$ 69.22$ from Cincinnati, and $\$ 102.58$ from St. Louis. The five-city average of the differential costs was $\$ 52.32$ per ton in 1816 , noticeably above the average shipping cost of $\$ 50.49$ on the southern route.

These figures still greatly understate the increased transportation costs that would have resulted if the Mississippi River had closed in 1816. First, Detroit and Chicago were unimportant at the time in western trade. Therefore a better estimate of the average transportation cost increase for western exports to New York is based on the figures for Pittsburgh, Cincinnati, and St. Louis. The average cost of shipping a ton of freight directly east 


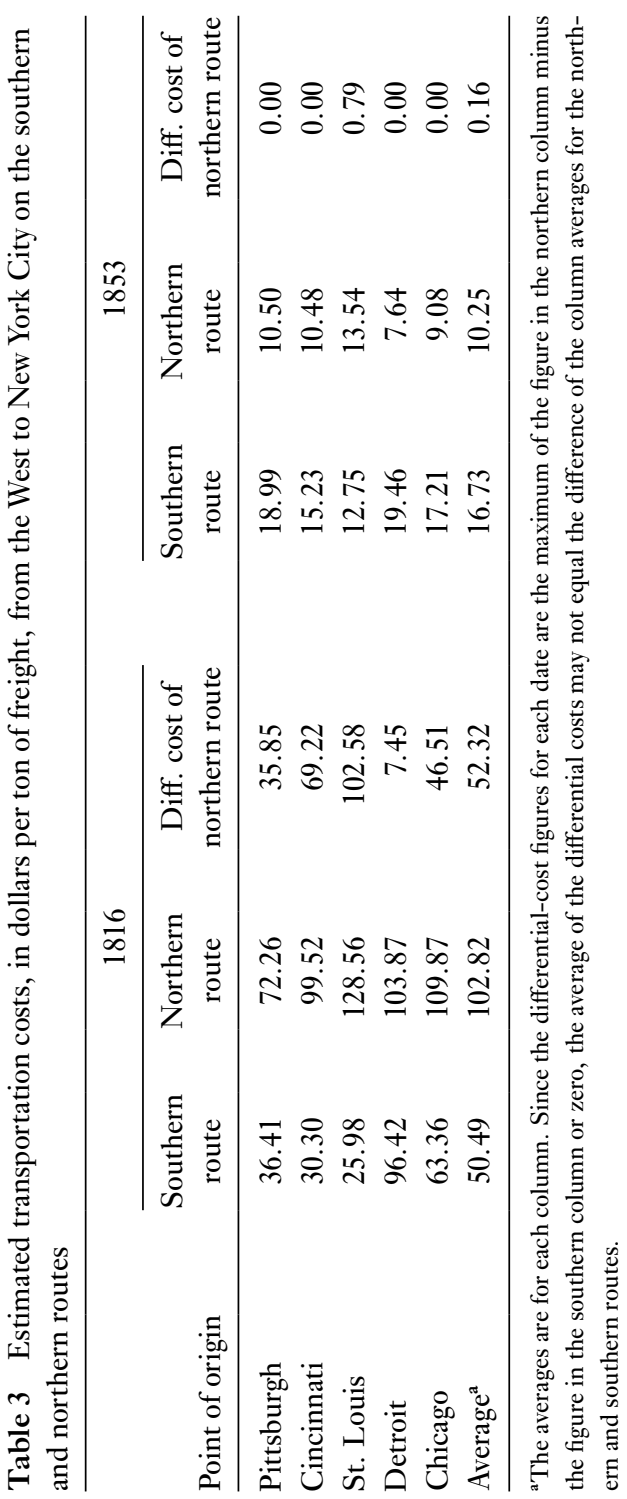


from these three cities was $\$ 100.11$, almost $\$ 70.00$ greater than the average of $\$ 30.90$ on the southern routes.

Second, in 1816 much of the western exports went to the Caribbean and Latin America. For this trade the route through New Orleans was the direct route, and rerouting it through the East Coast would have been more expensive than rerouting exports to New York City (Binder 2009). Third, the preceding figures treat prevailing freight rates as constant. They are therefore not reasonable estimates of the increase that would have occurred if all freight sent by the southern routes to nonsouthern consumers had switched to the northern routes. The supply curve over the direct route was inelastic, since the short run is relevant, the capacity of shippers on this route was small, and there would have been a large increase in the demand on the direct route (ibid.).

The estimated shipping costs from the West to New York City in 1853 are reported in the 1853 panel of table 3 . The effects of the transportation revolution are clear. The average transportation cost for the five cities on the New Orleans routes was $\$ 16.73$ per ton in 1853 , a noticeable decrease from the average in 1816. The costs of using the southern routes ranged from $\$ 12.75$ per ton (from St. Louis) to $\$ 19.46$ per ton (from Detroit). The costs of using the northern routes decreased over time by even more. The average transportation cost for the five northern routes east in 1853 was $\$ 10.25$ per ton, compared to $\$ 102.82$ in 1816 . The shipping costs on the northern routes in 1853 ranged from $\$ 7.64$ per ton from Detroit to $\$ 13.54$ per ton from $\mathrm{St}$. Louis. In 1853 the cities on the Great Lakes had lower shipping costs to the East than the river cities, in complete contrast to 1816. Thus St. Louis went from having the lowest transportation costs to New York in 1816 to having the highest in 1853 .

The estimates for 1853 are again consistent with western history. By the 1850 s the Great Lakes region was heavily populated, since it was costeffective to export produce from there, and by 1853 Chicago had virtually displaced St. Louis as the hub of western commerce. In 1853 the bulk of western exports to eastern and foreign consumers was shipped directly east, because the direct route was cheaper in almost every case. ${ }^{21}$ Even shippers in St. Louis sometimes used the northern route (De Bow's Reviem 1847: 101-6).

Estimates of the increase in transportation costs if the direct routes to New York City were used are in the third column of the 1853 panel of table 3 . The figure is positive ( 79 cents per ton) for St. Louis but 0 otherwise. Not 
surprisingly, the Republican Party's stronghold was in the upper Midwest, which had the lowest costs of rerouting trade with the East (Craven 1957: chaps. 13-14). For the five western cities, the average differential cost is only $\$ 0.16$ cents per ton in 1853 , as opposed to the average for the three river cities of $\$ 69.22$ per ton in 1816 .

While the differential transportation costs in 1853 are, like the estimates in 1816, understated, the bias is smaller in this case. First, the five-city average of the differential costs is relevant in 1853, because Chicago and Detroit were active then. Second, because most western exports to the non-South went directly east in 1853 , rerouting the remainder would have caused a much smaller increase in rates on the direct routes than in 1816 . Therefore not only is the estimate of average differential cost in table 3 in 1853 smaller than in 1816 , but the downward bias is smaller, making the differential costs of using the northern routes dramatically smaller in 1853 . In 1860 , when few western exports to the non-South went downriver, the increase in transportation costs of closing the river would have been even smaller than in 1853 .

The estimated costs of shipping from New York City to the West are in table 4. The costs in 1816 are in the 1816 panel of the table, with an average cost of shipping to the West via New Orleans of $\$ 148.56$ per ton. The costs per ton ranged from $\$ 114.28$ to $\$ 170.72$. These figures are much higher than the costs of shipping to New York City, because upstream freight rates were much greater than downstream rates in 1816. The costs of shipping a ton of freight west on the northern routes ranged from $\$ 118.14$ (to Detroit) to $\$ 167.40$ (to St. Louis). It was cheaper to ship to Detroit and Chicago than to the river cities on the northern routes because the overland freight rates were lower between Albany and Buffalo than between Philadelphia and Pittsburgh. The five-city average cost of shipping directly west was $\$ 143.28$ in 1816.

The transportation cost estimates are consistent with the known facts about eastern exports to the West. Unlike western exports, much of the traffic to the Ohio Valley went directly west in 1816 (Berry 1943: 71-80; Taylor 1976: 159). Also, the West imported few nonsouthern goods, since the cost was very high. An upper-bound estimate of the quantity of nonsouthern goods shipped to the West through New Orleans is 10,630 tons in 1816, which is one-sixth of western exports to the non-South over that route. ${ }^{22}$

The differential costs of using the northern routes in 1816 are reported in the third column of the 1816 panel of table 4 . For three of the five western 


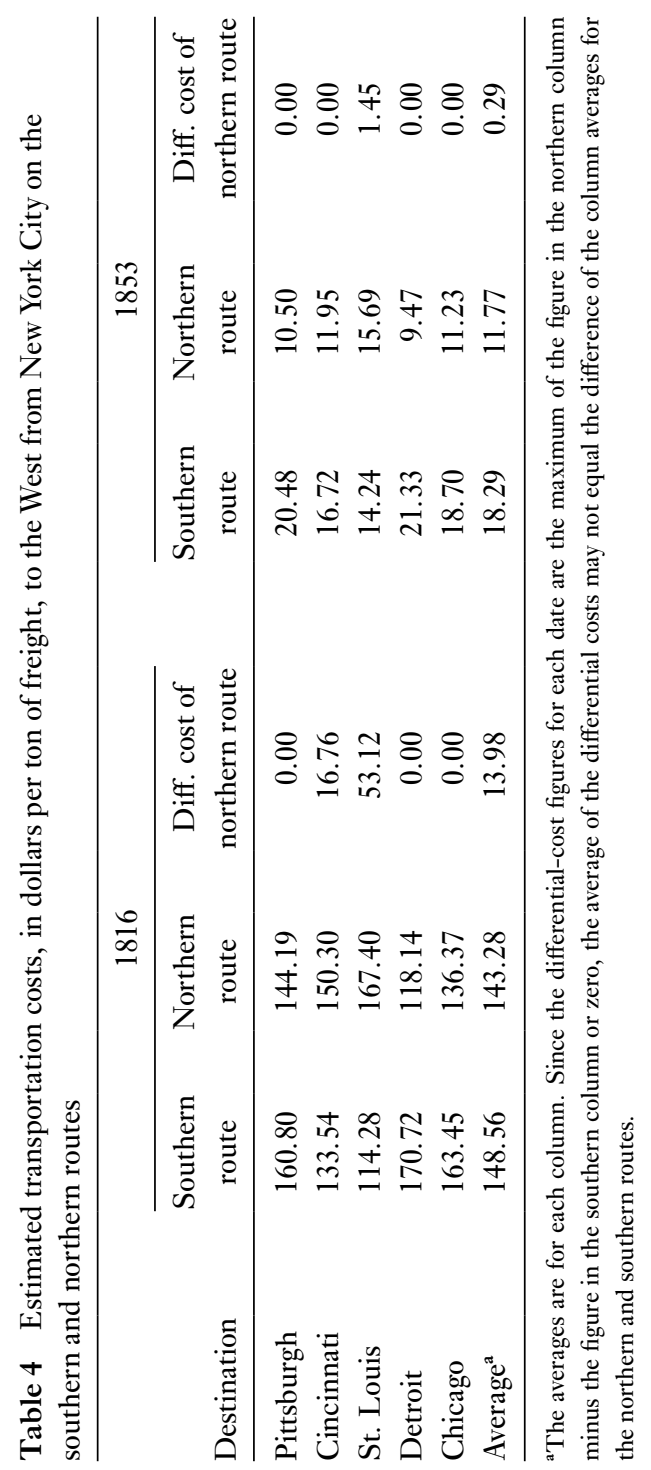


points, the differential cost was 0 before the transportation revolution. The costs were positive for Cincinnati (\$16.76) and St. Louis (\$53.12), and the five-city average is $\$ 13.98$ per ton. ${ }^{23}$ For western imports, the average differential costs underestimate the true costs of rerouting nonsouthern shipments west because the three-city average is indicative of the true costs, some of the imports came from Latin America and the West Indies, and the freight rates on the direct routes would have increased if shipments to the West were rerouted.

The average differential cost for St. Louis, Cincinnati, and Pittsburgh is $\$ 23.29$ per ton, almost $\$ 10$ greater than the figure for all five cities. However, this is still noticeably below the three-city average differential cost of rerouting western exports in 1816 of $\$ 69.22$. Also, non-European imports were less important than exports in 1816 . For Cincinnati, only coffee, less than 10 percent of its imports in 1826, was from Latin America or the Caribbean (Berry 1943: 328, table 24).

Third, while the closing of the Mississippi River would have increased the demand on the northern routes from New York City, the effect would not have been smaller than for western exports, since a larger percentage of the shipments from the East already used the direct route in 1816. No more than 10,630 tons shipped from the non-South to the West went via New Orleans in 1816, while 4,500 tons went directly west through Pittsburgh around this time. Also, the direct routes west would have primarily sent eastern goods downstream on the Ohio, causing no increase in downstream rates since extra capacity (handling some 62,000 tons) would have been available if exports no longer went downstream. Therefore the increase in westbound freight rates from New York City if southern routes had closed in 1816 would not have been trivial but would certainly have been much smaller than the increase in eastbound rates on the same routes. ${ }^{24}$

The estimated shipping costs from New York City in 1853 are reported in the 1853 panel of table 4 . The average cost of shipping a ton of freight to the West in 1853 on the southern routes was $\$ 18.29$, while shipping costs on the northern routes averaged only $\$ 11.77$ per ton. The figures are, for each type of route, similar to the eastbound freight rates in 1853 . The effects of the transportation revolution are again evident, except that the decrease in freight rates from 1816 to 1853 on both the northern and the southern routes was greater for westbound than for eastbound shipments. ${ }^{25}$ The shipping costs from New York City in 1853 are again consistent with the history of 
commerce. For example, western consumption of eastern and foreign goods increased noticeably as the transportation revolution progressed. The direction of this trade also changed as more goods shipped to the interior traveled by the lakes and canals as opposed to by ocean and river (Taylor 1976: 153-64).

The differential costs of using the northern routes from New York are in the third column of the 1853 panel of table 4 . As with the shipments from the West, in four of five cases the estimate of differential cost is 0 . Only in the case of St. Louis was the northern route more expensive, by $\$ 1.45$ per ton. For the five western cities, the differential cost of shipping west on the direct route from New York in 1853 is on average only $\$ 0.29$ per ton, compared to the average in 1816 for the three river cities of $\$ 23.29$.

As discussed for the eastbound traffic, the cost increases that would have resulted in 1853 from rerouting westbound shipments to the northern routes are probably understated but less than for the 1816 figures. The estimates of differential cost for westbound freight in 1853 are, however, probably biased downward more than those for eastbound shipments. While in both cases in 1853 the five-city average is relevant, rerouting the westbound trade via New Orleans would have had a greater effect on freight rates on the northern routes, because a greater percentage of western imports than exports still used the southern routes. ${ }^{26}$ Overall, the decrease in the differential costs over time was much smaller for goods sent west than for produce sent east.

In sum, in 1816 the costs of rerouting trade from the West to the nonSouth were quite large. While the costs of rerouting shipments to the West were positive in 1816, they were noticeably less than the costs of rerouting western exports, because both the estimates of the differential costs and the downward bias in those estimates are higher for the western exports to the non-South than for the nonsouthern goods shipped to the West.

\section{Changes in Transportation Costs over Time}

A more detailed examination of transportation costs over time provides insight into when they changed and the relative influence of the canals versus the railroads. Although data allowing a year-by-year comparison are not available, estimates (similar to those in table 3 ) for the southern route on a monthly basis and occasional newspaper reports of transportation costs on the northern route from Cincinnati are reported by Berry (1943: 88-92; 
Table 5 Estimates of the differential cost (per ton) of shipping from Cincinnati

\begin{tabular}{lc}
\hline Year & $\begin{array}{c}\text { Diff. cost of } \\
\text { northern route }\end{array}$ \\
\hline 1816 & $69.22^{\mathrm{a}}$ \\
1840 & 5.88 \\
1843 & 2.60 \\
1845 & 1.68 \\
1846 & 1.60 \\
1847 & 0.32 \\
1848 & 4.12 \\
1849 & 0.32 \\
1853 & $0.00^{\mathrm{a}}$ \\
1860 & $0.00^{\mathrm{b}}$ \\
\hline
\end{tabular}

${ }^{\mathrm{a}}$ From table 3. A similar estimate for 1853 is obtained from the figures in Berry 1943.

${ }^{\mathrm{b}}$ Assumed to equal to zero, as in 1853 .

561-62, table 10) beginning in 1840. The estimates of differential cost based on these figures are in table 5 .

While the shipping costs from Cincinnati on the northern route were noticeably above those on the southern route in 1816, the canals caused a substantial decrease in the differential cost and reduced it to about $\$ 6$ a ton in 1840 . The differential cost continued to decline, barring the aberration in 1848 , throughout the 1840 s and equaled about $\$ 2$ a ton in the middle of the decade. By 1850 transportation costs on the northern and southern routes were almost equal. Of course, the figures would be different for other cities, but, given Cincinnati's location, they should be similar to the average for Mississippi and Ohio river shipping points.

Of further interest is the percentage of western exports to the nonSouth that used the southern route. From essentially 100 percent in 1816, this figure declined to 38 percent in 1839,33 percent in 1844,32 percent in 1849,18 percent in 1853,15 percent in 1857 , and finally 3 percent in 1860 (Fishlow 1965: 284, table 39). The canals had the greatest impact, because by the mid-1840s only a third of the western produce consumed in the East or abroad went by the southern route. But the railroads had a noticeable impact as well, reducing this figure to less than 5 percent by 1860 .

The fact that the difference in existing transportation costs was small during the 1840s does not mean that the costs of rerouting western exports to the non-South were politically unimportant at that time. Throughout the 
1840s about one ton of western exports to the non-South still used the southern routes for every two tons shipped on the northern routes. Shifting this trade to the northern routes would have greatly increased transportation costs on these routes, because short-run supply curves were inelastic (especially during the peak shipping season). For example, from 1857 to 1872 the rates for shipping wheat and corn on the Great Lakes were frequently three times higher in the fall than in the spring (St. Louis Merchants' Exchange 1874: 52). This increase would have been borne by all western exports, not just those that would otherwise have gone through New Orleans. Therefore, while the costs of rerouting western exports decreased greatly from 1816 to 1840 , they continued to decline during the 1840 s and 1850 s.

\section{The Political Effects of the Transportation Revolution}

\section{The Costs of Switching to the Direct Routes}

On the surface, the differential costs of shipping by the northern route in 1816 appear to be large, at least for western exports. To be politically important, the effects of closing the Mississippi River must have been large enough to noticeably impact individuals' wealth. This section examines the effect of rerouting commercial and other traffic on each region's share of gross domestic product (GDP).

GDP for the United States in 1816 was $\$ 830$ million (Sutch and Carter 2006). If product per capita were constant across the regions, the gross product of each region could be estimated by multiplying GDP by regional population percentages. While data for 1840 and 1860 indicate that per capita income differed across regions, the ratio of western income per capita to national income per capita was the same each year (Easterlin 1961). Therefore this ratio is assumed to be constant from 1816 to 1860 , and western gross product during this period is estimated as the 1840 ratio of western GDP to U.S. GDP times U.S. GDP per capita times total western population for the year. ${ }^{27}$ The value of goods and services produced in the West in 1816, which is much smaller than that in the South or the East, is estimated as $\$ 44.3$ million.

One method to estimate the effect on the West of closing the Mississippi River in 1816 is based on the rule of thumb that transportation costs could not exceed 50 percent of the market price of a good (see Atack and Passell 
Table 6 The effect of the loss of western trade with the non-South (via New Orleans) on the western economy

\begin{tabular}{lccccc}
\hline Year & $\begin{array}{c}\text { Western } \\
\text { exports } \\
\text { lost (tons) }\end{array}$ & $\begin{array}{c}\text { Western } \\
\text { exports lost } \\
\text { (millions of \$) }\end{array}$ & $\begin{array}{c}\text { Other } \\
\text { revenues lost } \\
\text { (millions of \$) }\end{array}$ & $\begin{array}{c}\text { Western gross } \\
\text { product } \\
\text { (millions of \$) }\end{array}$ & $\begin{array}{c}\text { \% of gross } \\
\text { product lost }\end{array}$ \\
\hline 1816 & 62,031 & 4.3 & $0.9-1.4$ & 44.3 & $11.7-12.9$ \\
1839 & 63,425 & 4.6 & $0.5-0.8$ & 261.9 & $1.9-2.1$ \\
1844 & 107,384 & 4.2 & $0.6-0.8$ & 285.2 & $1.7-1.8$ \\
1849 & 282,065 & 12.4 & $1.6-2.3$ & 388.8 & $3.6-3.8$ \\
1853 & 202,190 & 12.9 & $1.5-2.2$ & 618.1 & $2.3-2.4$ \\
1857 & 182,812 & 16.6 & $1.2-1.9$ & 844.9 & $2.1-2.2$ \\
1860 & 104,740 & 8.2 & $0.7-1.0$ & 929.6 & $1.0-1.0$ \\
\hline
\end{tabular}

1994: 47). If the data for Cincinnati are at all indicative, western exports to the non-South would have completely ceased if the Mississippi River had been closed before the transportation revolution. ${ }^{28}$ Based on the Cincinnati average price per ton of $\$ 69.32$ in 1816 - a reasonable estimate of western prices on average, since that city was about average distance from New York for western points of importance at the time-and 62,031 tons of western produce exported to the non-South, western exports would have decreased by $\$ 4,299,989$ if sectional disagreement had closed the southern route in 1816. ${ }^{29}$ This and other data for the western economy in 1816 are on the first line of table 6 .

This figure includes only part of the effect on the western economy. First, the West provided transportation services that would also have decreased. Based on an estimated average transportation cost from the West to New Orleans of $\$ 17.85$ a ton and 62,031 tons exported to the non-South, the costs of shipping these exports to New Orleans are estimated as $\$ 1,107,253$ in $1816 .{ }^{30}$ If one-half to three-fourths of this service (which is a lower-bound estimate, because most of it was shipped on flatboats manned by westerners) was provided by the West, then western output would have declined by between $\$ 553,627$ and $\$ 830,440$ due to the decrease in transportation services.

Second, there was passenger as well as commercial traffic between the sections. While it is difficult to estimate how much western output was due to travel from the West to the non-South, the transportation services related to this traffic can be estimated. Albert Fishlow (1965: 34, table 2) estimates 
that in 1859 railroad passenger revenues were equal to 65 percent of freight revenues. If a similar relation held between transportation services for freight and passengers in 1816, then it is estimated that western output would have declined by between $\$ 359,858$ and $\$ 539,786$ due to the loss of transportation services for passenger traffic with the East and foreign countries.

Summing the estimates for the declines in western exports and transportation services yields an estimate of the decline in western gross product in 1816 of between $\$ 5,213,474$ and $\$ 5,670,215$ if intercourse between the West and the non-South had been lost due to closure of the Mississippi River. This is between 11.7 and 12.9 percent of western gross product and is equivalent to a significant economic depression. It should be reiterated that these figures understate the effect on the West, because they do not take into account the total effect on travel by westerners, the effects of decreased imports of eastern and foreign goods on the western economy, or the effect of lower farm incomes on the demand for other western goods and services. Nonetheless, it appears that if sectional conflict had closed the Mississippi River in 1816, the West would have been greatly hurt.

Similar calculations (see table 6) are used to estimate the effect on the western economy if all trade with the non-South via New Orleans had been lost after 1816. These are upper-bound estimates of the actual harm to the West's economy, because most of this trade would have been rerouted as opposed to totally lost. In 1839 the upper-bound estimate is that western gross product would have decreased by about 2 percent due to southern interference with western exports to the non-South. This figure decreased further during the mid-1840s, only to rise again, given the increase in western exports, by the end of the decade to over 3 percent. The percentage effect on the western economy declined steadily during the 1850 s until 1860 , when the maximum impact on the West is estimated as a decrease in regional gross product of 1 percent. These estimates, even though upward-biased for the years after 1816, indicate that the cost to the West of politically antagonizing the South decreased noticeably over time to almost nothing in 1860 due to the transportation revolution.

While the potential economic effects of sectional conflict on the West in 1816 were significant, the effects on the East at that time were much less important. As discussed above, eastern exports to the West were a fraction of western exports to the non-South in 1816, and the costs of rerouting this trade were also substantially smaller than for western exports. Because the 
gross product of the East was much greater than that of the West, sectional conflict in 1816 would have had a small effect on eastern gross product per capita. Therefore closure of the southern route before the transportation revolution would have been unimportant in eastern political calculus.

The costs of political disagreement with the South did not change noticeably over time for the East, because westbound transportation rates did not decline as much as those in the opposite direction and because the per capita effect for the East was small. The main effect on the East of conflict with the South at any time would have been the loss of its exports to and imports from the South. Not surprisingly, the eastern stance toward the South-especially that of businesspeople-did not change dramatically because of the transportation revolution (Foner 1941). Southerners would have been the least affected (directly) by the decrease in the costs of rerouting East-West trade, because they were merely the middlemen in this commerce. A civil war at any time would have caused the South to lose its trade with the East and the West but little more. Because alienating the South before the transportation revolution would have led to economic catastrophe north of the Ohio River, it is hard to imagine the West pursuing such a strategy. Therefore the transportation revolution removed a major obstacle that deterred the West from disagreeing politically with the South. This affected the political equilibrium (if the political views of the West and the South were different), because the West held the balance of power between the sections (see, e.g., Craven 1957: chap. 13, esp. 312). Of course, the political change did not immediately follow the decrease in the differential costs of shipping, because it takes time for such changes to translate into effective political action. For example, the extension of slavery was an issue as early as 1848, when Martin Van Buren ran for president as the Free Soil candidate, but the Republican Party did not craft a winning coalition until 1860 .

\section{Population Effects}

Several historians have linked railroad expansion and antebellum political change (see the summary in Channing 1925, 6: chap. 13). First, the railroads brought to the West easterners and European immigrants, whose political views (it is claimed) differed from those of transplanted southerners. ${ }^{31}$ The second hypothesis is that the western railroads increased communication and interaction between westerners and easterners, because trade and 
people now flowed directly east-west. Simultaneously, westerners had less contact with southerners. This, it is believed, led westerners to adopt eastern opinions and attitudes. ${ }^{32}$ The third argument is that railroads changed the amount of trade between the East and the West (since the costs of transporting goods decreased). While more of their produce was consumed by easterners, westerners consumed more and higher-quality eastern manufactured goods and came to be more sympathetic to the East than to the South (Cotterill 1917: 438).

By focusing on the railroads, these arguments ignore the canals. Also, none of the studies presents any statistical evidence; with one exception (Jervey 1909), they also provide little evidence that these changes were understood at the time. It is difficult to test the second hypothesis, because attitudes in the West and the degree of social interaction are not quantifiable. However, evidence can be brought to bear in the other two cases. Statistical evidence does not support the argument that trade noticeably increased between the East and the West in a manner that would have influenced western political opinions. For example, between 1839 and 1860 the percentage of western goods consumed in the South decreased only slightly, from 18 percent to 14 percent (Fishlow 1965: 278, table 36; 284, table 39).

The first hypothesis, that railroads (and canals) changed western demographics and political views, is examined in greater detail below. It should be noted, however, that the transportation revolution affected northern and western population in other important ways. By increasing the relative population of the North, the North's numerical superiority over the South in men of military age and the probability that the North would win an armed conflict increased. ${ }^{33}$ This was especially important because the South possessed most of the best generals (McPherson 1982: 48-50). In 1820 the North outnumbered the South in men of fighting age by a ratio of 2.33 to 1 . In 1840 this ratio was 2.86 to 1 , and in 1860 it was 3.31 to $1 .{ }^{34}$ This assumes that the West would have aligned with the East. If the West had fought with the South, eastern numerical superiority would have been much smaller in 1820 and virtually nonexistent in 1840 . Therefore the East would have thought twice about conflict with the South before the transportation revolution had run its course.

The effect of the transportation revolution on the number of free white men of military age is examined by regressing the decennial change in this variable for each northern state, MILITARYAGE, against the change in 
the state's canal mileage, CANAL, and railroad mileage, RR. The data are from 1830, 1840, 1850, and $1860 .{ }^{35}$ The estimated regression equation (with $t$-statistics in parentheses) is:

$$
\begin{gathered}
\text { MILITARYAGE }=23,886.14+69.52 \mathrm{CANAL}+52.97 \mathrm{RR} \\
(6.45)(2.47) \\
N=60, R^{2}=.48
\end{gathered}
$$

Both of the estimated slope coefficients are significant at less than the 1 percent level in one-tailed tests. While a mile of canal brought about as many people to a northern state as a mile of track, the railroads had the greatest effect, because in the North from 1820 to 1860 railroads grew by 21,078 miles, canals by only 3,989 miles. Together these two improvements in transportation account for, when the coefficient estimates in the preceding regression are multiplied by the mileage increases, 1,395,178 of the roughly 3.2 million increase in the number of men of fighting age in the North from 1820 to 1860.

Most of this effect occurred during the 1850s, when about two-thirds of northern track was constructed. Subtracting the increase due to railroads and canals from the actual figure for the North in 1860 yields an estimate of the North to South ratio of fighting age men in 1860 if the transportation revolution had not occurred of only 2.18 to 1 , which is a decrease from $1820 .{ }^{36}$ Therefore the transportation revolution greatly increased the North's numerical superiority over the South.

The total population of the West also increased between 1820 and 1860 , bringing more free states into the Union and giving them a numerical advantage in the Senate and in the House of Representatives. Politically, this resulted in 16 free states versus 15 slave states after Iowa, Wisconsin, and California became states. When Kansas was admitted in 1861, there were 19 free states as opposed to 15 slave states.

When decennial changes in total population, POP, for the northern states are regressed against the variables CANAL and RR using data from 1830 to 1860 , the results are qualitatively similar to those obtained in the regression examining the variable MILITARYAGE. The estimated regression line is:

$$
\begin{gathered}
\mathrm{POP}=112,513.38+369.72 \mathrm{CANAL}+237.04 \mathrm{RR} \\
(6.67) \quad(2.90) \\
N=60, R^{2}=.48
\end{gathered}
$$


The coefficient estimates are about five times larger in the latter regression, because men of fighting age were about one-fifth of the total population. As in equation (2), the increase in railroad mileage had a much greater effect than canal growth on total northern population due to the larger increase in railroad miles in the North. This effect, measured either by the increase in total northern population or by the change in the balance in the Senate, was also greatest during the $1850 \mathrm{~s}$.

Before Abraham Lincoln's election, the free states' numerical advantage in the Senate may not have troubled the slave states greatly, because the free states could not override a presidential veto, the likely response by Lincoln's predecessors to any laws onerous to the slave states. But with a cooperative Republican president, the free states could put into law whatever they wished. The slave states therefore had reason to be concerned after Lincoln's election.

If the South is defined as the 11 states that eventually seceded, the North's advantage was 44 to 22 in the Senate in 1859, and, if the voting had been along sectional lines, the North would have been able to override vetoes by Lincoln in both houses of Congress. Some northern (border-state) senators might have voted against legislation repugnant to the South, but with the admission of Kansas, Nevada, and Nebraska on the horizon, the South would have seen the handwriting on the wall in 1860 . Within a few years the North would have an unstoppable majority in Congress.

Regarding changes in nativity in the North, data on the number of people in each northern state born in Germany, England, Ireland, the South, and other areas are collected from the 1850 and 1860 federal censuses. Of the people born in other areas, over 94 percent came from the northern states. Similar to equations (2) and (3), the decennial change in the size of each group is regressed against changes in railroad and canal miles in each state. ${ }^{37}$ The results are reported in table 7 .

The regression results indicate that the railroads did bring more German, Irish, and English immigrants (as well as northerners) to the northern states in the $1850 \mathrm{~s}$. The coefficient estimates on the variable RR are positive and statistically significant at less than the 1 percent level in all four regressions. While each mile of railroad brought about 32 Germans, 19 Irish, and 7 people from England to a state, it increased the number of people of other (largely northern) nativity by about 200 . Because the railroads did not bring 
Table 7 The effects of canal and railroad building from 1850 to 1860 on the nativity of the northern population

\begin{tabular}{lcccc}
\hline Nativity & Constant & CANAL & RR & $R^{2}$ \\
\hline German & $9,557.46$ & 0.57 & 32.43 & .50 \\
& $(2.74)$ & $(0.01)$ & $(7.78)$ & \\
English & $2,485.44$ & -33.37 & 7.22 & .48 \\
& $(2.58)$ & $(2.31)$ & $(7.20)$ & \\
Irish & $16,613.22$ & 31.64 & 18.84 & .15 \\
& $(3.22)$ & $(0.30)$ & $(4.10)$ & \\
Other & $58,464.23$ & -237.54 & 207.47 & .65 \\
& $(2.67)$ & $(0.57)$ & $(5.67)$ & \\
Southern & $21,403.35$ & -169.80 & 9.08 & .03 \\
& $(2.64)$ & $(1.07)$ & $(0.63)$ & \\
\hline
\end{tabular}

Note: The variables are measured as decennial changes, and the figures in parentheses are $t$-statistics (in absolute value); $N=19$.

more southerners to the North, this changed the nativity of the population in the East and the West.

None of the coefficient estimates on the variable CANAL is reliably greater than zero in one-tailed tests at the 5 percent level. On the surface, this seems to indicate that the canals did not increase northern population. This appears to be a statistical artifact, however. Because there was little canal building during the $1850 \mathrm{~s}$, there is little variation in CANAL (as opposed to RR). The standard errors on these coefficient estimates are 10 to 20 times larger than those for the coefficient estimates on RR, which decreases the power of the tests. For example, if equations (2) and (3) are reestimated using just the decennial change from 1850 to 1860 , the estimated coefficients on RR are statistically significant, while those on CANAL are negative (as is largely the case in table 7). Therefore, if data on nativity were available before 1850 , statistical tests would likely show that canals and railroads had a similar effect per mile on nativity in the North. The fact that railroad building (at minimum) brought more foreigners and northerners with it does not necessarily mean that this changed political behavior, because not all of these groups favored Lincoln in 1860. For example, Richard H. Steckel (1998: esp. 598, table 9) finds that German immigrants generally voted Democratic, while Irish, English, and other voters strongly supported Lincoln. Based on Steckel's results and those in table 7, the effect of railroad building in the 1850 s on the percentage of the total votes received by Lincoln in each north- 
ern state in 1860 is estimated ${ }^{38}$ On average, the miles of railroad added during the 1850s increased the percentage of the voters casting a ballot for Lincoln in the northern states by about 1 percent.

How was the South affected by these changes? Formerly, it existed side by side with a West that held similar political views. Even if those views had been different, the West's antagonizing the South would have come to nothing politically, given the balance in the Senate. Furthermore, a war would have ruined the western economy and may have been unwinnable by the North, given the manpower on both sides and the importance of western foodstuffs to the northern army.

After the transportation revolution, the South faced a hostile West, which was unconcerned about the Mississippi River being closed, and (more broadly) a North with a great numerical advantage in fighting men, in the size of its economy (due in part to total northern population), and in Congress. The South seceded to protect itself from what it saw as further abuse. If the South had stayed in the Union after Lincoln's election, the North could have passed legislation offensive to it. Ending slavery itself required a constitutional amendment, which would not have passed in 1861, but the North could have ended slavery in the territories and brought in many more free states. Expecting secession, it could also have dispossessed the South of military resources over time. In the South's mind, it was better to go in 1861 than later, when the North's military advantage would be even greater.

\section{Political Awareness of the Transportation Revolution's Effects}

The transportation revolution was not politically important unless its implications were recognized at the time. Various statements by prominent northerners and southerners show that the political ramifications of the transportation revolution were well understood in terms of its effects on trade and western population.

By the 1830s the South realized that northern internal improvements were decreasing the commercial ties between it and the West and hurting their political relations. Influential southerners proposed building a railroad from Charleston, South Carolina, to Cincinnati, Lexington, and Louisville. It was hoped that this connection would capture the trade of the Ohio and Mississippi valleys and keep the West tied to the South. For example, in 
1835 Robert Y. Hayne noted the effects the proposed road would have on the political controversy over slavery:

We allude to the effect which such a connection must have upon the peculiar institution of the South. Slavery as it now exists in the Southern States . . is so little understood in other portions of the Union that it has lately been assailed in a spirit which threatens ... to lead eventually to the destruction of the Union, and all the evils which must attend so lamentable an occurrence. We believe that an establishment of such an intercourse with the Western States, as is now proposed, would have a powerful tendency to avert this dire calamity. (Quoted in Jervey 1909: 388)

Similarly, John C. Calhoun wrote in a letter dated September 30, 1835, that "I have long considered [the proposed line to the Ohio River] the most important in the whole range of internal improvements" and that he had no doubt "of its immense importance, commercially, politically and socially" (quoted in Wilson 1959, 12: 557). Calhoun stated more strongly, in a letter to Hayne on October 28, 1838, that "I believe the success of a connection of the West is of the last [sic] importance to us politically and commercially" (see American Historical Association 1900: 411; see also Wilson 1959, 13: 264, $271 ; 17: 108,190)$. The importance of transportation connections between the South and the West was stressed repeatedly by decision makers from both regions during the 1830 s at various commercial and railroad conventions. For instance, the Cincinnati Convention of 1835 supported the railroad to Charleston and argued that, if it was built, "the north [sic] and South would, in fact, shake hands with each other, yield up their social and political hostility, pledge themselves to common national interests, and part as friends and brethren" (quoted in Ward 1986: 45). The Indiana legislature also supported the railroad in a resolution because of "its effect on the social and political condition of our common country" (quoted in Jervey 1909: 396). The resolution stated further: "[It] will tend by its operations upon the trade and intercourse of remote and comparatively alienated sections of this confederacy to harmonize the jarring elements of now discordant conflicting interests, feelings and habits; . . . which will evidently tend to connect with new ties this glorious Union, which is the basis of our common prosperity and of well-regulated liberty" (ibid.).

Similar statements were common during the 1840s. In 1846 the influential editor J. D. B. De Bow commented on the commercial proposals made at 
the Memphis Convention of Southern and Western States. He believed that if the South and West were linked commercially, ${ }^{39}$

they are bound together by ties which can never be severed. Amid all the bitterness and jealousies which political influences have begotten, there is too much in common between these sections, too many similar interests exist, too many sympathies and connections, for them ever to act otherwise than united. Bound together in this way their destinies are one. Elevated or depressed, it must be together. No other sections in this Union have reasons so strong for maintaining their interesting relation. (De Bow's Review 1846a: 20)

The West and South were still closely tied during the 1840s due to the importance of the Mississippi River in intersectional commerce. For example, Elihu Burritt of Worcester, Massachusetts, argued: "Dissolution of the Union? - What! cut in two the Mississippi, that jugular vein of the New World, and sever all the mighty arteries of the Union, and leave it to bleed to death in hostile segments, both writhing in the cauteries of mutual hatred? Nature itself would repel this profane disruption" (Southern and Western Liberty Convention 1845: 3-4). In the same vein, Governor Crittenden of Kentucky said in December 1849 that the Mississippi Valley "would never consent to destruction of the Union which would close the Mississippi River to its exports," since the Union was a "necessity" to the valley and to Kentucky (quoted in Kirwan 1962: 246). ${ }^{40}$

Arguments about the implications of transportation for sectional politics continued in the 1850s. In August 1851 De Bow bemoaned the lack of railroad connections between the South and the West: "Our prosperity is interrupted by causes which tend to separate us in interests and in feelings; and thus it is that we seem incapable of alliance for any great purpose, whilst other sections of the Union constitute, so far as their interests are concerned, always a unit" (De Bow's Reviem 1851: 143). ${ }^{41}$ Edward Bates (1852: 12) of St. Louis wrote to De Bow on December 10, 1851: "Without the railroads the system will be incomplete; with them, this mighty valley will present one compact and indissoluble whole, each part of which will reciprocate benefits and blessings with all the rest." Senator Isaac P. Walker from Wisconsin described the Illinois Central Railroad in 1850 as "a great chain to unite the North and South," while Stephen Douglas remarked similarly: "There is a power in this nation greater than the North or the South.... That power is the coun- 
try known as the great West - the Valley of the Mississippi, one and indivisible from the Gulf to the Great Lakes, and stretching, on the one side and the other, to the extreme sources of the Ohio and Missouri. ... There, Sir, is the hope of this nation - the resting place of the power . . . to save, the Union" (both quoted in Milton 1963: 12). More generally, William H. Seward, speaking in the Senate on April 29, 1850, called internal improvements connecting the West and the South "necessary thoroughfares-necessary not only for themselves, but for the whole country - necessary for the welfare and prosperity, and even for the existence of the Union" (quoted in Baker 1853: 306). Sectional concerns over the route of the transcontinental railroad led Jefferson Davis (1859: 17) to respond: "The Senator attributes to me the desire to secure a southern location ... [for] sectional advantage. ... It has been constantly assumed that the South are most eager, for sectional purposes and advantages, to get the road diverted to the thirty-second parallel."

Statements during the secession crisis indicate that it was understood at the time that closing the Mississippi River would cause the North little harm. For example, Charles A. Davis (1861) of New York City noted that "since Railroads have intervened [?] there can be no divisions between the people of the Mississippi Valley north of Kentucky (including that state) and all East \& north East." Henry C. Carey (1876: 2) recounted a conversation he had had with Lincoln in May 1861 (see also Carey 1869: 2-5):

"What was it that even then held the Union together? Was it not the Mississippi?" "Yes," said he [Lincoln], "that is the cross-tie." "Well, then," as I continued, "if you had an iron cross-tie down the Valley and through the mountain region to Alabama and the Gulf, and another from the Ohio through East Tenneessee [sic] to Charleston and Savannah, do you think it would be possible to dissolve the Union?" "No," said he, "it would then be entirely impossible."

Similar statements appear in newspaper editorials. Daniel Lord (1861: 39-40), the editor of the New York Times, argued vigorously that "the free navigation of the Mississippi, which only a few years ago was considered indispensable, is for the North-Western States an imaginary rather than a real necessity." He added that "the peaceable effect of Secession may be to close its mouth, in which event the entire trade of the Valley could be easily ... sent over Northern and Eastern routes.” In the same vein, the Cincinnati Daily Commercial stated on January 25, 1861, "The truth is, we may 
not reasonably apprehend that the commerce of the Mississippi Valley will be long or seriously interrupted or embarrassed by any difficulty arising from the Secession movement" (quoted in Perkins 1964: 548). More strongly, the New York Times (1862) concluded that the rebellion would have succeeded if the North did not have the canals and railroads to export foodstuffs to Europe in order to avoid bankruptcy.

Statements about Population and

Political Equilibrium

Prominent individuals were also aware of the growth in northern versus southern population due to the transportation revolution and how this affected the sections. Mr. Burmell, a delegate to the Southern and Western Trade Convention, argued:

The great secret of Northern supremacy ... was that the great emigration from foreign countries pours in at their sea ports, and that there is and always has been more people at the North than at the South. . . De Witt Clinton might be called the greatest enemy of the South; for it was him that started the great New York canals, which have developed the resources of that great State, and added so greatly to its present position. (quoted in New York Times 1852)

Similarly, the Nem York Times (1856) stated: "The Senate must remain what it is, until by the admission of several Free States the Southern preponderance be destroyed. It is by pushing forward Railroads to the crystallizing States of the Northwest, that we can bring them into the Union; [therein] lies, in all likelihood, the solution of the political problem, the difficulties of which now convulse the nation.” Edmund Ruffin (1857a: 585) of Virginia wrote in 1857:

There will be admitted other Senators from four or five new nonslaveholding States, which increase will make the abolition party as irresistible in the Senate, as it is already in the other branch of Congress. When this party is thus supreme, it will, of course, elect a President of the United States of like sentiments. And then . . all that is . . necessary for their [the southern states] very existence, will be at the mercy of their fanatical and determined enemies. 
Ruffin (ibid.: 585-86) continued: "Owing to [foreign immigrants], it will not be long before the non-slaveholding States will ... make three-fourths of the whole number of the members of the Confederacy. Then, the Federal Constitution may be legally altered in any manner by the votes of the Northern States only." This explains why the South was eager for slavery in the territories. Without it, eventually three-fourths of the states would support a constitutional amendment abolishing slavery. Therefore limits on the spread of slavery were a longer-run threat to the continued existence of the institution itself.

How could the South protect itself from this mounting threat? W. Sykes (1852: 540) of Tennessee stated the common southern view: "They think that in the course of a few years several additional free states will be admitted into the Union; . . . and that the free states . . will either attempt to change the Constitution, or will so construe it as materially to affect the rights of the South. . . . therefore they are in favor of seceding from the Union now." In fact, in a letter written in 1847 John C. Calhoun argued for secession because "we are now stronger relatively than we shall be hereafter politically and morally. Unless we bring on the issue, delay to us will be dangerous indeed" (quoted in New York Times 1855).

\section{Conclusion}

This article argues that the transportation revolution had several important political effects. First, it caused western and southern political views to differ. Second, it greatly reduced the expected costs to the West of political disagreement, because the costs of rerouting western exports decreased. Third, it increased western population, which brought more free states into the Union and changed the equilibrium in the Senate. Fourth, it increased northern numerical and economic superiority over the South and therefore the probability that the North would win an armed conflict. While the first effect (focusing on the railroads) has been discussed previously, the others seem to have gone largely unnoticed.

Together, these changes appear to have been important enough to cause the West to ally with the East against the South, changing the antebellum political equilibrium. Confronted by a hostile North, which was growing politically and militarily stronger every day, the South feared that its rights 
would be violated, including the eventual abolishment of slavery itself. The South seceded in the hope of protecting itself.

Although most of the decrease in the costs of rerouting western exports to the non-South occurred before 1850 , the other changes took place during or continued into the $1850 \mathrm{~s}$. Several of these changes were likely necessary for the West to alter its political stance. For example, even if the West had been hostile to the South and heavily populated, it is unlikely that it would have quarreled with the South if this would have greatly hurt the western economy. Even if the costs of rerouting western exports had been small, however, it is unlikely that the West would have quarreled with the South if the political views of the two regions were similar or if a war with the South were unwinnable.

\section{Notes}

I am grateful to David Barker, David Galenson, Bob Korajczyk, David Olster, Michael Perman, Jon Pritchett, David Surdam, several anonymous referees, and seminar participants at Northwestern University, the University of Chicago, the University of Illinois at Chicago, and Wheaton College, whose suggestions at various stages greatly improved the article. The assistance of the staff at the University of Chicago Library, especially the Special Collections Research Center of the Joseph Regenstein Library, is greatly appreciated. Finally, I am deeply indebted to the late Merton Miller, who taught me how to see the relations between seemingly unrelated things.

1 A. L. Kohlmeier (1938) notes that the routing of western commerce had political implications but does not fully appreciate the effects. He concludes that the commerce of the West and its political stance did not greatly change due to the transportation revolution.

2 This section draws heavily on Nevins 1947; Craven 1957; Holt 1978, 2004; Foner 1980: chap. 3; and Sibley 2005. On slavery and its extension, see also Fogel 1989; Freehling 1990, 2007; and Egnal 2009.

3 The argument presented here and most of those that follow do not depend on any particular issue(s) being the reason for the disagreement. They are consistent with any issue(s) being the bone of contention between the sections.

4 The probability of secession and/or civil war, given that the sections disagree, could be less than 1 without affecting the implications. Also, the subjective probabilities of a section winning a war might have differed across individuals or sections.

5 Since individual preferences are being examined, per capita costs and benefits are relevant.

6 In 1816, 80 percent of the receipts by river at New Orleans were produce from the West, indicating that it was at the time a major exporter. See Callender 1909: 313-21 
and Taylor 1976: 158-59. E. Bogart and D. L. Kemmerer (1947: 300) note that western exports were sent largely to the East Coast and to foreign markets.

7 R. W. Fogel (1964) gives an overview of U.S. railroad construction vis-à-vis the canal system and its effects on national wealth. C. Goodrich (1960) and R. E. Shaw (1990) provide excellent discussions of canal and railroad building.

8 In 1860 there were still no railroads in Kansas, Nebraska, or Minnesota.

9 See the maps in Stover 1978.

10 While in most cases the routes and methods of transportation are fairly obvious, in a few instances clarification is required. For example, the only effective means of transportation between Philadelphia and Pittsburgh in 1816 was wagon. Similarly, Buffalo and Albany were connected by road. See Berry 1943: 70-74 and Meyer 1948: 84-89. Also, goods were shipped between Philadelphia and New York City by wagon alone in 1816, as opposed to river and wagon, since the transportation costs were similar (Taylor 1976: 443, table 3).

11 Several alternative routes are also examined. In each case they are more expensive than the routes shown in the table.

12 In 1853 the Erie Canal carried over 1.2 million tons of western produce east, while the four trunk-line railroads together carried only 200,000 tons (Callender 1909: 342).

13 The standards for a ton are from De Bow's Reviem 1846b. Albion 1965: app. 7 provides data on New York to New Orleans rates in 1836.

14 For example, on the Erie Canal east- and westbound shipping charges differed, while the rate for a short haul on Lake Erie (Detroit to Toledo) was usually the same as for a longer one (Detroit to Buffalo), making the rates per ton mile different. A general outline of the data collection is given here, with the details provided in an appendix (available from the author on request). The freight rates from Taylor and McAlpine are for shipping a ton of freight (or a ton per mile). These rates are most likely based on the general rate per hundredweight. Since much of the antebellum freight was classified this way, the Taylor and McAlpine figures should accurately estimate transportation costs. Several of the freight rates are based on specific commodities. In two cases in 1853 when the McAlpine estimates are not used, the rate per ton is based on the rate for a barrel of flour, while in another case the average rate on flour, wheat, and corn is used. The 1853 freight rate from New York City to New Orleans is based on the general merchandise rate. Similarly, the rates per ton in 1816 between New Orleans and New York City and from the upper Great Lakes to Buffalo are based on the rates for cotton and flour, respectively.

15 When the rate is quoted by container, the ocean freight standard for a ton is used to calculate the freight per ton, as in Berry 1943: 58n45.

16 For a detailed discussion of the antebellum period, see Morrison 1858; Plumb 1911; Hulbert 1920; Berry 1943: chaps. 1-5; Meyer 1948; Taylor 1976: chaps. 1-8; and Bauer 1988.

17 Advances in sailing and the use of steam power were responsible for the decline in the water transportation rates. 
18 The lengths of the route segments are from a variety of sources, including transportation and canal histories, Army Corps of Engineers maps, and the author's estimates.

19 In 1820 Chicago and Milwaukee did not exist, Detroit had 1,422 residents, and Cleveland township had 606 residents. In contrast, the populations of Pittsburgh, Cincinnati, and St. Louis were 7,248; 9,642; and 10,049, respectively (U.S. Census Office 1821).

20 Niles' Register (1818: 14) reports that a transportation line had been established between New York City and Detroit. Military supplies and manufactured items may have been transported to Detroit, but it is doubtful that produce from there could compete in eastern markets with that from the lower West.

21 Berry (1943: 91, table 5) analyzes the trade of Cincinnati. From 1850 to 1852 most of the total exports from that city of flour, barreled pork, and whiskey went downriver (96.7, 92.8, and 85.0 percent, respectively). From 1859 to 1861 the downriver percentages for the same exports were markedly smaller $(19.6,58.0$, and 62.8 percent, respectively). These figures include southern as well as eastern and foreign consumption.

22 Author's estimate using available data on upriver shipments (for a portion of the upstream traffic) during the early 1820 s and data on downriver shipments to New Orleans by various routes to estimate the total tons shipped from New Orleans (Binder 2009: 53n39).

23 Unlike shipments from the West, which were first cheaper by the southern route and then cheaper by the northern route, shipments from the East were cheaper for some western cities first by the northern route, then cheaper by the southern route for several years, and finally cheaper again by the northern route. This is because the costs of shipping west via New Orleans dropped due to the use of steamboats after 1817 , making the southern route cheaper than the direct route until the canals and railroads permanently reversed the inequality (see Berry 1943: 80-83).

24 Because east- and westbound shipments over the direct routes are jointly produced and because, after East-West trade was rerouted, there may have been excess capacity for westbound shipments by wagon, the increase in westbound shipping rates over the direct routes may have been even smaller than implied, because westbound wagon rates would have increased only slightly.

25 On the northern routes, rates from New York City declined more than those to New York City, because the transportation revolution replaced relatively expensive wagon transportation with canals, whose freight rates in each direction were fairly similar. Also, the difference between eastbound and westbound rates on the Great Lakes was much smaller in 1853 than in 1816. On the southern routes, rates from New York City declined more than those to New York City, because by 1853 upstream rates on the Mississippi and Ohio rivers equaled downstream rates and ocean rates to New Orleans were similar to rates from there.

26 Taylor (1976: 164) estimates that about one-third of the western imports from the East were shipped by the southern route in 1851 . 
27 According to R. Easterlin (1960), the ratio of western GDP per capita to U.S. GDP per capita was 0.72 in 1840 .

28 These estimates are reported in an earlier draft of this article (Binder 2009: 19-21). Similar results are obtained for St. Louis and Pittsburgh.

29 This assumes that the value of western produce consumed in the West remains constant.

30 Using Cincinnati as an average western shipping point, the average cost of shipping to New Orleans is estimated as 1,373 miles times $\$ 0.013$ per ton mile, or $\$ 17.85$ per ton.

31 See the statements by Albert Pike (quoted in De Bow's Reviem 1854:210) and William Burwell (1856: 473-74). R. R. Russel (1918: 352) and F. J. Turner (1920: 135-42) note that the railroads brought many easterners into the West.

32 See Phillips 1908: 396; and Jervey 1909: 388, 401-2, 458, 465. J. M. McPherson (1982: 8) argues that the "reorientation of trade patterns strengthened interregional ties among the free states."

33 The West comprises Illinois, Indiana, Iowa, Kansas, Michigan, Minnesota, Missouri, Nebraska, Ohio, and Wisconsin. The South comprises Alabama, Arkansas, Florida, Georgia, Kentucky, Louisiana, Mississippi, North Carolina, South Carolina, Tennessee, Texas, and Virginia. The East comprises the remaining states east of the Rocky Mountains that had been admitted to the Union by 1861 .

34 In 1820 this figure is the number of free white males from 18 to 44 years old. In 1830 , 1840 , and 1850 the age group is 20 to 49 years old. In 1860 it is 18 to 45 years old.

35 The railroad mileage figures are from Poor 1868: 20-21. Canal mileage data for 1830, 1840, and 1850 are from Meyer 1948: 573, table 82, and canal mileage in 1858 ( $D e$ Bow's Reviem 1858: 102-5) is used to estimate mileage in 1860 . The population data are from the U.S. Census Office 1821.

36 When decennial population changes for the southern states are regressed against changes in railroad and canal mileage, both estimated slope coefficients are statistically insignificant in one-tailed tests at the 5 percent level. Therefore southern population was not affected by the transportation revolution.

37 Kansas is omitted from the sample, because there are no nativity statistics for it in the 1850 census.

38 The details of this estimation appear in a previous draft of this article (Binder 2009: 31-32).

39 A similar resolution was passed at the convention in November 1845 (De Bow's Reviem 1846a: 19).

40 Edmund Ruffin (1857b: 603) made the same argument in 1857, when 15 percent of western exports to the non-South still went downriver.

41 He also stated that the effects of more railroads for the South and the West would include "the promotion of commerce; the removal of prejudices; the strengthening of bonds of harmony and peace" (De Bow's Reviem 1851: 145). 


\section{References}

Albion, R. (1965) Square Riggers on Schedule. Hamden, CT: Archon.

American Historical Association (1900) Annual Report 1899, vol. 2. Washington, DC: U.S. Government Printing Office.

Atack, J., and P. Passell (1994) A New Economic View of American History. New York: Norton.

Baker, G. E., ed. (1853) The Works of William H. Seward. New ed., vol. 1. New York: Redfield.

Bates, E. (1852) “Letter from the Hon. Edw. Bates of Missouri.” De Bow's Review, May, 568-69.

Bauer, K. J. (1988) A Maritime History of the United States. Columbia: University of South Carolina Press.

Berry, T. S. (1943) Western Prices before 1861. Cambridge, MA: Harvard University Press.

Binder, J. J. (2009) "The transportation revolution and antebellum sectional disagreement." Working paper, November.

Bogart, E., and D. L. Kemmerer (1947) Economic History of the American People. New York: Longmans, Green.

Burwell, W. M. (1856) "The policy of the South: Suggestions for the settlement of sectional differences." De Bow's Review, November, 469-90.

Callender, G. S. (1909) Selections from the Economic History of the United States. Boston: Ginn.

Carey, H. C. (1869) Letters to the President. Philadelphia: Lippincott. (1876) To the Friends of the Union throughout the Union. Philadelphia: n.p.

Channing, E. (1925) A History of the United States. New York: Macmillan.

Cotterill, R. S. (1917) “Southern railroads and western trade, 1840-1850.” Mississippi Valley Historical Review 3: 427-41.

Craven, A. (1957) The Coming of the Civil War. Chicago: University of Chicago Press.

Davis, C. A. (1861) Letter to John J. Crittenden, January 21. Crittenden Papers, University of Kentucky.

Davis, J. (1859) Speech of the Honorable Jefferson Davis of Mississippi on the Pacific Railroad Bill. Baltimore, MD: Murphy.

De Bow's Review (1846a) “The Convention of the Southern and Western States.” January, 7-21.

(1846b) "Southern and western commerce." February, 171-76.

(1847) "Contests for the trade of the Mississippi Valley." February, 98-111.

(1851) "Address to the people of the southern and western states." August, 142-75.

(1854) "The Great Southern Convention in Charleston, no. 3." August, 200-213.

(1858) “Canals in the United States.” July, 102-5.

Easterlin, R. (1960) "Interregional differences in per capita income, population, and total income, 1840-1950," in Conference on Research in Income and Wealth (ed.) Trends 
in the American Economy in the Nineteenth Century. Princeton, NJ: National Bureau of Economic Research: 73-140.

(1961) "Regional income trends, 1840-1950," in Seymour E. Harris (ed.) American Economic History. New York: McGraw-Hill: 525-46.

Egnal, M. (2009) Clash of Extremes. New York: Hill and Wang.

Fishlow, A. (1965) American Railroads and the Transformation of the Antebellum Economy. Cambridge, MA: Harvard University Press.

Fogel, R. W. (1964) Railroads and American Economic Growth: Essays in Econometric History. Baltimore, MD: Johns Hopkins University Press.

(1989) Without Consent or Contract: The Rise and Fall of American Slavery. New York: Norton.

Foner, E. (1980) Politics and Ideology in the Age of the Civil War. New York: Oxford University Press.

Foner, P. S. (1941) Business and Slavery. Chapel Hill: University of North Carolina Press. Freehling, W. W. (1990) The Road to Disunion, vol. 1. Oxford: Oxford University Press.

\section{— (2007) The Road to Disunion, vol. 2. Oxford: Oxford University Press.}

Gienapp, W. E. (1987) The Origins of the Republican Party, 1852-1856. New York: Oxford University Press.

Goodrich, C. (1960) Government Promotion of American Canals and Railroads. New York: Kennikat.

Holt, M. F. (1978) The Political Crisis of the 1850s. New York: Wiley. (2004) The Fate of Their Country. New York: Hill and Wang.

Hulbert, A. B. (1920) The Paths of Inland Commerce. New Haven, CT: Yale University Press.

Jervey, T. D. (1909) Robert Y. Hayne and His Times. New York: Macmillan.

Kirwan, A. D. (1962) John J. Crittenden: The Struggle for the Union. Lexington: University of Kentucky Press.

Kohlmeier, A. L. (1938) The Old Northwest. Bloomington, IN: Principia.

Lord, D. (1861) The Effect of Secession upon the Commercial Relations of the North and South. New York: New York Times.

McAlpine, W. J. (1854) Documents of the Senate of the State of New York, no. 60. Albany, NY: Van Benthuysen.

McPherson, J. M. (1982) Ordeal by Fire. New York: Knopf.

Meyer, B. (1948) History of Transportation in the United States before 1860. Washington, DC: Carnegie Institute.

Milton, G. F. (1963) The Eve of Conflict: Stephen A. Douglas and the Needless War. New York: Octagon.

Morrison, J. H. (1858) History of American Steam Navigation. New York: Daye.

Nevins, A. (1947) Ordeal of the Union. New York: Scribner.

New York Times (1852) “The southern trade convention.” December 20.

- (1855) "Retaliation or disunion - letter from John C. Calhoun.” June 27.

(1856) "A railroad to Kansas." May 9.

(1862) “The Illinois and Michigan Canal.” March 3. 
Niles' Register (1818) “Chronicle.” February 28, 14.

North, D. (1966) The Economic Growth of the United States, 1790-1860. New York: Norton.

Perkins, H. C., ed. (1964) Northern Editorials on Secession. Gloucester, MA: Smith.

Phillips, U. B. (1908) History of Transportation in the Eastern Cotton Belt. New York: Columbia University Press.

Plumb, R. G. (1911) History of Navigation on the Great Lakes. Washington, DC: U.S. Government Printing Office.

Poor, H. V. (1868) Manual of the Railroads of the United States, 1868-1869. New York: Poor.

Riker, W. (1982) Liberalism against Populism. San Francisco: Freeman.

Ruffin, E. (1857a) “Consequences of abolition agitation, no. 1.” De Bow's Review, June, 583-93.

- (1857b) “Consequences of abolition agitation, no. 5." De Bow's Review, December, 597-607.

Russel, R. R. (1918) "A revaluation of the period before the Civil War: Railroads." Mississippi Valley Historical Review 15: 341-54.

Shaw, R. E. (1990) Canals for a Nation. Lexington: University Press of Kentucky.

Sibley, J. H. (2005) Storm over Texas. Oxford: Oxford University Press.

Southern and Western Liberty Convention (1845) The Address of the Southern and Western Liberty Convention. Cincinnati, OH: n.p.

St. Louis Merchants' Exchange (1874) Memorial of the Union Merchants' Exchange of St. Louis to the Forty-third Congress of the United States. St. Louis, MO: Studley.

Stampp, K. (1990) America in 1857. New York: Prentice-Hall.

Steckel, R. H. (1998) "Migration and political conflict: Precincts in the Midwest on the eve of the Civil War.” Journal of Interdisciplinary History 28: 583-603.

Stover, J. (1978) Iron Road to the West. New York: Columbia University Press.

Sutch, R., and S. B. Carter, eds. (2006) Historical Statistics of the United States. Millennial Ed. Online. New York: Cambridge University Press, hsus.cambridge.org/ HSUSWeb/HSUSEntryServlet.

Sykes, W. (1852) "The development of southern resources: The best guarantee for the protection of southern rights.” De Bow's Review, May, 540-42.

Taylor, G. R. (1976) The Transportation Revolution, 1815-1860. White Plains, NY: Sharpe.

Turner, F. J. (1920) The Frontier in American History. New York: Holt.

U.S. Census Office (1821) Census for 1820. Washington, DC: U.S. Government Printing Office.

Ward, J. A. (1986) Railroads and the Character of America, 1820-1887. Knoxville: University of Tennessee Press.

Wilson, Clyde, ed. (1959) The Papers of John C. Calhoun. Columbia: University of South Carolina Press. 